\title{
A Review on Internal Combustion Engine Fins
}

\author{
Mukesh Kumar Singh \\ M.tech Scholar \\ Department of Mechanical Engineering \\ Millenium Institute of Technology \\ Bhopal, Madhya Pradesh, India
}

\author{
Prof. H. S. Sahu \\ Assistant Professor \\ Department of Mechanical Engineering \\ Millenium Institute of Technology \\ Bhopal, Madhya Pradesh, India
}

\begin{abstract}
Extended surfaces has its major significance in heat transfer and thermal management in internal combustion engine they plays a major role in performance of combustion engines, In this paper heat transfer effectiveness of fins were studied also with literature survey to identify the previous works that have been performed by mathematical, analytical and numerical methods with optimizing profiles, materials and process parameters, this survey paper segmented and clustered the detail description of internal combustion engine fins, This paper reviews the recent researches that were performed in heat sinks by considering various parameters and methods.
\end{abstract}

Keywords-Convection, fins, heat dissipation, thermal analysis, Air cooled engines, Water cooled Engines, Heat transfer coefficient.

\section{INTRODUCTION}

Internal combustion engines are part of economic development in world economy in present era the goods that are exported imported by means of heavy vehicles like trucks and buses are working in internal combustion engine, although passenger vehicles and civil construction heavy vehicles also works in internal combustion engines these engines generates high amount of heat during working, this heat is dissipated by means of fins with air cooled, oil cooled and water cooled engine systems.

The cooling of engines thoroughly depends upon the fins, it is classified as:

- Air cooled engines

- Oil cooled engines

- Water cooled engines

Air cooled engines - these type of engines are used in both spark ignition and compression ignition engines it consists of fin in combustion cylinder the air direct interacts with cylinder, thus cylinder gets cooled by means of fins.

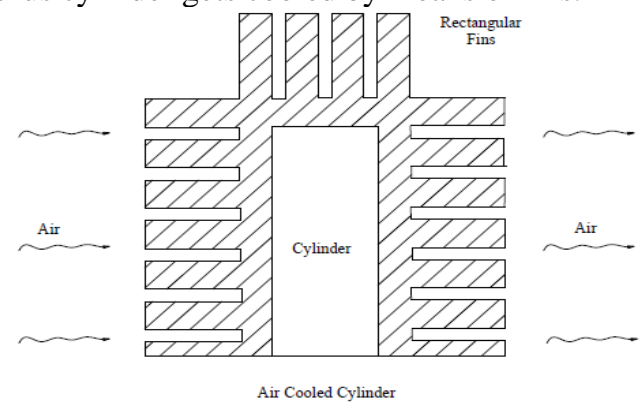

Figure 1 - Air cooled engine fins

Oil and Water cooled engines - Oil Cooled and Water Cooled engine with fin configuration are terms employed by manufacturer's to identify the slight difference between the cooling systems. Oil cooling: Technically, An oil cooled engine is an air cooled with oil cooling assistance, the bulk of the thermal effectiveness transfer is from the fins on the engine block. Air-cooled engines are predominantly fuel efficient, economical and require lesser engine area as compared liquid cooled engines. The upkeep costs of liquid cooled ones are above air-cooled engines [28].

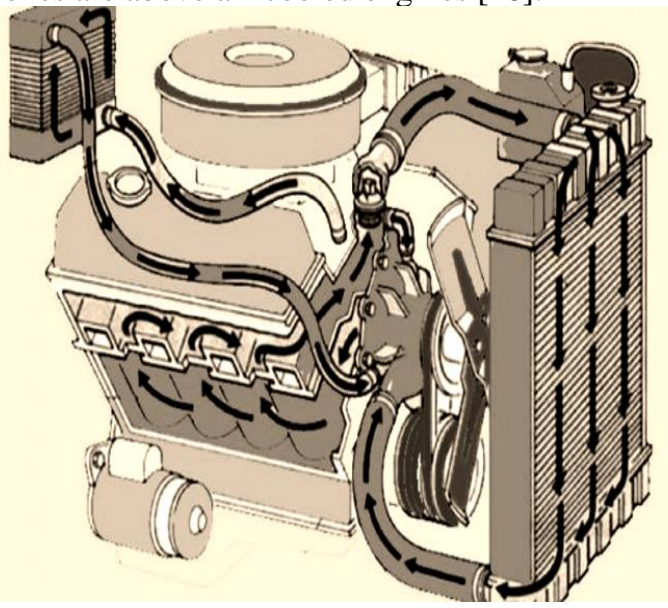

Figure $2-$ Water cooling engine fins.

\section{COOLING FINS}

1. Fins are the extruded surfaces created to extend heat transfer rate for a definite surface temperature, or to decrease surface temperature for a defined heat transfer rate [27].

2. Heat transfer by convection between two surfaces and therefore the fluid around the surface are often increased by fabricating to the surface called fins [27].

3. The conduction of heat through solids, walls, or boundaries has got to be dissipated to the environment or environment to maintain the system during a steady-state condition. In many engineering applications large quantities of thermal exchange is needed to be dissipated from tiny areas [27].

4. The fins increase the effective surface area of a any model thereby increasing energy transfer by convection. Rectangular fin and triangular fins are straight fins. Triangular fins are attractive, since for an equivalent heat transfer it needs much low volume than rectangular fins. Hence the fins have practical importance because it gives maximum heat flow per unit mass with easy manufacture [27]. 


\section{STRUCTURE OF FIN}

The structure of fin supports in effectiveness of heat dissipation, many researchers have proposed different shape of fins and predicted the heat transfer effectiveness in different heat flux as well as parametric evaluation have been performed by varying fin thickness, fin spacing and length of fin, the different type of fin structures are:

- Rectangular fin

- Offset strip fin

- Triangular fin

- Perforated fin

- Wavy fin

- Louvered fin

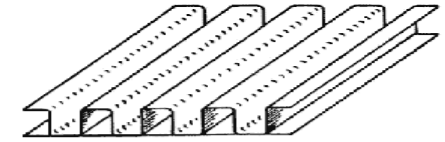

(a) Rectangular

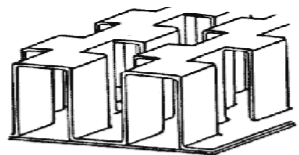

(d) Offset strip fin

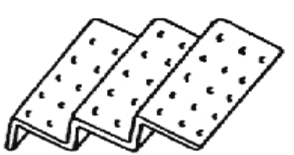

(e) Perforated

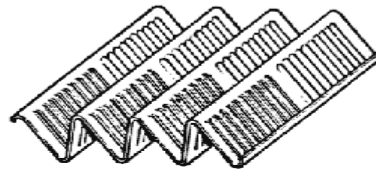

(f) Louvered (c) Wavy

Figure 3 - Classification of fins.

Many of researchers investigated variable outcomes in analysis of fin by performing numerical simulation, mathematically and experimentally, the survey had been done on different types of fin shape to predict behavior of heat dissipation and temperature distribution [1], further material of fin is changed to predict behavior of heat flux and temperature distribution including different shapes of fin [2], the effect of convection condition with conduction on fins were analyzed for improvement in higher heat dissipation [3], natural convection analysis had been performed in fins using software simulation with finite element method for determination of high thermal effect and compared outcome results obtained by variable parameters [4], proposed design of fin considering transient fuel as a working fluid with analyzing distribution of heat with optimization in design of fin [5], the potency of different fins by optimizing their form were reviewed for prediction of thermal efficiency, the review is also done for prediction the thermal effects on fins by finite volume method and finite element method [6], effective cooling performance is analyzed by varying fin thickness, fin spacing. The analysis is performed in ANSYS software by applying parametric evaluation and determined optimum dimensions for effective cooling performance [7], combination of circular and strapped fin with magnesium and alumunium 6061 were used to enhance the heat transfer rate using finite element method [8], further the survey has been performed in four stroke spark ignition engines, the different configurations with materials were predicted and study was done on variable profile of cylinder block that were used in different vehicles [9], thermal performance of fins that were performed using finite element method in different materials were evaluated with highly thermal conductive materials [10].

\section{LITERATURE SURVEY}

The investigations that were performed in internal combustion engine fins are elaborated below:

\begin{tabular}{|c|c|c|c|}
\hline $\begin{array}{l}\text { Type of } \\
\text { investigation }\end{array}$ & Type of fin & $\begin{array}{l}\text { Materials } \\
\text { used }\end{array}$ & Results obtained \\
\hline $\begin{array}{l}\text { Numerical } \\
\text { simulation } \\
\text { (ANSYS) [11] }\end{array}$ & Slotted fins & $\begin{array}{ll}\text { Aluminum } & \text { Alloy } \\
6061 & \\
\text { Aluminum } & \text { Alloy } \\
\text { C443 } & \\
\text { Aluminum } & \text { Alloy } \\
2014 & \\
\end{array}$ & $\begin{array}{l}\text { Aluminum Alloy } \\
2014 \text { with the slot } \\
\text { width } 75 \mathrm{~mm} \\
\text { enhances more heat } \\
\text { dissipation. }\end{array}$ \\
\hline $\begin{array}{l}\text { Numerical } \\
\text { simulation } \\
\text { (CFD, Fluent) } \\
{[12]}\end{array}$ & Helical fins & Aluminum Alloy & $\begin{array}{l}\text { Fin pitch of } 187 \mathrm{~mm} \\
\text { performed optimal } \\
\text { thermal performance. }\end{array}$ \\
\hline $\begin{array}{l}\text { Particle } \\
\text { swarm } \\
\text { optimization } \\
\text { algorithm } \\
\text { (MATLAB } \\
\text { R2010a) [13] } \\
\end{array}$ & ular & Aluminum Alloy & $\begin{array}{l}\text { The multi-objective } \\
\text { optimization results } \\
\text { are more satisfactory }\end{array}$ \\
\hline $\begin{array}{l}\text { Numerical } \\
\text { simulation } \\
\text { [14] }\end{array}$ & nned & Aluminum Alloy & $\begin{array}{lr}\text { Schmidt } & \text { fin } \\
\text { efficiency } & \text { improved } \\
\text { by7.0\%. }\end{array}$ \\
\hline $\begin{array}{l}\text { Numerical } \\
\text { simulation } \\
\text { (AUTODESK } \\
\text { INVENTER) } \\
{[15]}\end{array}$ & ins & $\begin{array}{l}\text { Aluminum Alloy } \\
6061\end{array}$ & $\begin{array}{l}\text { A fin with fillet edges } \\
\text { enhances more heat } \\
\text { transfer. }\end{array}$ \\
\hline $\begin{array}{l}\text { Experimental } \\
{[16]}\end{array}$ & ned & Aluminum Alloy & $\begin{array}{l}\text { The developed } \\
\text { empirical relationship } \\
\text { enhances temperature } \\
\text { distribution. }\end{array}$ \\
\hline $\begin{array}{l}\text { Numerical } \\
\text { simulation } \\
\text { (AUTODESK } \\
\text { INVENTER) } \\
{[17]} \\
\end{array}$ & $\begin{array}{l}\text { Surface } \\
\text { roughened } \\
\text { fins }\end{array}$ & $\begin{array}{l}\text { Aluminum Alloy } \\
6061\end{array}$ & $\begin{array}{l}250 \text { micron, } 300 \\
\text { micro and } 400 \\
\text { micron surface } \\
\text { roughened enhances } \\
\text { more heat transfer } \\
\end{array}$ \\
\hline $\begin{array}{l}\text { Numerical } \\
\text { simulation } \\
{[18]}\end{array}$ & anted pin & Aluminum Alloy & $\begin{array}{l}\text { Temperature } \\
\text { distribution } \\
\text { enhanced. }\end{array}$ \\
\hline $\begin{array}{l}\text { Numerical } \\
\text { simulation } \\
\text { (CFD, Fluent) } \\
{[19]}\end{array}$ & $\begin{array}{l}\text { Circular pin } \\
\text { fin }\end{array}$ & Aluminu & $\begin{array}{l}\text { Improved distribution } \\
\text { of heat }\end{array}$ \\
\hline $\begin{array}{l}\text { Numerical } \\
\text { simulation } \\
{[20]}\end{array}$ & Plat & Aluminu & $\begin{array}{l}4 \% \text { of improvement } \\
\text { in temperature } \\
\text { distribution is } \\
\text { observed. }\end{array}$ \\
\hline
\end{tabular}

P.Senthilkumar et al.[21] - in this study design of circular fin has been done by finite element method, the investigation is performed by comparing the different profiles of fin with determination of thermal stress also the parameters were compared in form of temperature distribution, heat flux as well as structure of fin.

YangXu et al. [22] - investigated thermal performance by parametric evaluation with different configuration of pin fin including impingent flow, the final observation is the optimum ratio of distance between fin and spacing ratio develops maximum heat transfer characteristic in inclusion if impingent flow.

Su MinHoi et al. [23] - the study represents a fractal shaped inserts in plate fin heat sink to enhance convective heat transfer, increase in heat transfer is analyzed by varying thickness of fractal, the results were compared by evaluating 
Reynolds number with each optimized design of plate fin heat sink, this study also propose that fractal inserts with unity enhances overall thermal performance of plate fin heat sink. NgoctanTran et al. [24] - presented the configuration of louvered fins and improved $19.54 \%$ of thermal performance using forced convection the velocity ranges that were considered is between $1 \mathrm{~m} / \mathrm{s}$ to $6 \mathrm{~m} / \mathrm{s}$ with louvered angle between 27 degree to 40.5 degree the results are compared together and heat dissipation is improved.

LeiLi et al. [25] - The pin fins including the inner cavity increases the circular flow and make it move beneath, in order that the Nusselt number within the area below the pin fins is enhanced; meanwhile, local convective heat transfer coefficient and therefore the area of thermal exchange have both increased to enhance the convective heat transfer effect.

AdeelTariq et al. [26] - The experimental data validates the conjugate model of heat sink using finite volume method. The results from the FVM model show that the heat transfer coefficient is higher in the plane fins without slots and perforations. Also need of pumping power is compared to be less in comparison of base model.

\section{CONCLUSION}

After surveying several literatures of engine fin, the following conclusions were withdrawn,

1. More improvements could be made by considering the materials like graphene and aluminum foam.

2. Fins with different profiles of perforations should be used and would be analyzed for more improvement in heat transfer.

3. Pin fins with slanted edge would be employed in heat sink which would increase the heat transfer rate because slanted edge have capability to converge the flow, due to this effective cooling would be done.

4. It can be concluded that even performing the several attempts have been made to optimize several parameters related to fin for heat transfer augmentation, but still there is a huge scope for fin design modification and optimization.

\section{REFERENCES}

[1] Mr. Vibhav Sawant et al, "Review Paper on Optimisation of Fins by Modifying Geometry and Materials used for Production”, International Journal of Innovative and Emerging Research in Engineering, Volume 4, Issue 1, 2017.

[2] Vikash Kumar et al, "A Review Paper on Improving the Efficiency of IC Engine Fins by Varying its Material and Shape", International Journal of Recent Development in Engineering and Technology, SSN 2347-6435(Online) Volume 5, Issue 6, June 2016.

[3] Sushma S et al, "A Review on Enhancement of Heat Transfer through Fins", International Journal of Scientific and Research Publications, Volume 9, Issue 6, June 2019 ISSN 2250-3153.

[4] Prabhmeet Singh et al, "Review Comparison of Performance of Different Profiles of Fins using Thermal Analysis", International Journal of Recent Technology and Engineering (IJRTE) ISSN: $2277-$ 3878, Volume-4 Issue-1, March 2015.

[5] Mr. Uday Mishra et al, "A Review Paper on rising the potency of IC Engine Fins by varied its Material and form", International International Journal of Information Technology, Volume 5, Issue 6, June 2017

[6] Akash M Vyas et al, "Analysis of I.C. Engine Fins for Effective Cooling Performance", IJSTE - International Journal of Science Technology \& Engineering | Volume 5 | Issue 1 | July 2018.

[7] G. Babu et al, "Heat Transfer Analysis and Optimization of Engine Cylinder Fins of Varying Geometry and Material", IOSR Journal of
Mechanical and Civil Engineering (IOSR-JMCE) e-ISSN: 22781684,p-ISSN: 2320-334X, Volume 7, Issue 4 (Jul. - Aug. 2013), PP 24 29.

[8] Prof. Arvind S.Sorathiya et al, "Review Paper on Effect of Cylinder Block Fin Geometry on Heat Transfer Rate of Air-Cooled 4S SI Engine", International Journal of Recent Development in Engineering and Technology, ISSN 2347 - 6435 (Online) Volume 2, Issue 1, January 2014.

[9] Kummitha Obula Reddy et al, "Thermal Analysis of cylinder block with fins for different materials using ANSYS", Materials today: proceedings 4(8):8142-8148.

[10] Arvind S Sorathiya et al, "Review Paper on Effect of Cylinder Block Fin Geometry on Heat Transfer Rate of Air-Cooled 4S SI Engine", International Journal of Recent Development in Engineering and Technology (ISSN 2347 - 6435 (Online) Volume 2, Issue 1, January 2014).

[11] DivyankDubey et al, "Thermal Analysis of Engine Cylinder having thick tip fin with varying slot sizes and material", https://doi.org/10.1016/j.matpr.2017.07.097

[12] XiaoyuHu et al, "Numerical investigation of thermo-hydraulic performance of an opposed piston opposed cylinder engine water jacket with helical fins", Applied Thermal Engineering Volume 159, August 2019, 113824.

[13] HongdaLiuHongguangZhang et al, "Multi-objective optimization of fin-and-tube evaporator for a diesel engine-organic Rankine cycle (ORC) combined system using particle swarm optimization algorithm", Energy Conversion and Management Volume 151, 1 November 2017, Pages 147-157.

[14] LingdongGu et al, "Airside heat transfer and pressure loss characteristics of bare and finned tube heat exchangers used for aero engine cooling considering variable air properties", International Journal of Heat and Mass Transfer Volume 108, Part B, May 2017, Pages 1839-1849.

[15] PulkitSagar et al, "Heat transfer analysis and optimization of engine fins of varying geometry", https://doi.org/10.1016/j.matpr.2017.07.202.

[16] JieWen et al, "Thermal and hydraulic performance of a compact plate finned tube air-fuel heat exchanger for aero-engine", Applied Thermal Engineering Volume 126, 5 November 2017, Pages 920-928.

[17] PulkitSagar et al, "Heat transfer analysis and optimization of engine fins of varying surface roughness", https://doi.org/10.1016/j.matpr.2017.07.203.

[18] MinsungKim et al, "A numerical study on various pin-fin shaped surface air-oil heat exchangers for an aero gas-turbine engine", International Journal of Heat and Mass Transfer Volume 93, February 2016, Pages 637-652.

[19] EnhuaWang et al, "3D numerical analysis of exhaust flow inside a finand-tube evaporator used in engine waste heat recovery", Energy Volume 82, 15 March 2015, Pages 800-812

[20] EmanuelFeru et al, "Two-phase plate-fin heat exchanger modeling for waste heat recovery systems in diesel engines", Applied Energy Volume 133, 15 November 2014, Pages 183-196

[21] P.Senthilkumar et al, "Design and thermal analysis on circular fin", https://doi.org/10.1016/j.matpr.2020.02.784.

[22] YangXu et al, "Review Effect of pin fin arrangement on the heat transfer characteristics in a convergent channel with impingement", International Journal of Heat and Mass Transfer

[23] Su MinHoi et al, "Plate-fin heat sink forced convective heat transfer augmentation with a fractal insert", International Journal of Thermal Sciences Volume 142, August 2019, Pages 392-406

[24] NgoctanTranet al, "Optimization of the airside thermal performance of mini-channel-flat-tube radiators by using composite straight-andlouvered fins", International Journal of Heat and Mass Transfer Volume 160, October 2020, 120163

[25] LeiLi et al, "Convective heat transfer characteristics of twin-web turbine disk with pin fins in the inner cavity", International Journal of Thermal Sciences Volume 152, June 2020, 106303.

[26] AdeelTariq et al, "Comparative Numerical and Experimental Analysis of Thermal and Hydraulic Performance of Improved Plate Fin Heat Sinks", Applied Thermal Engineering Available online 26 August 2020, 115949.

[27] https://learnmech.com/types-of-fins-heat-transfer-equation/

[28] https://www.zigwheels.com/newbikes/faqs/what-is-air-and-oil-cooledsystem-and-how-it-is-different-from-liquid-coolingsystem/1212453/\#: :text=Air\%20and\%20oil\%20Cooled\%20engine,Th ey\%20have $\% 20$ the $\% 20$ fins $\% 20$ too. 